Intersections

Canadian Journal of Music

Revue canadienne de musique
Intersections

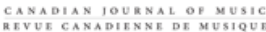

\title{
Ascending Music: Meaning and Expression in the Chamber Music of Brian Cherney
}

\section{Taylor Brook}

Volume 37, numéro 1, 2017

Illuminations: Essays in Honour of Brian Cherney

URI : https://id.erudit.org/iderudit/1059888ar

DOI : https://doi.org/10.7202/1059888ar

Aller au sommaire du numéro

\section{Éditeur(s)}

Canadian University Music Society / Société de musique des universités canadiennes

ISSN

1911-0146 (imprimé)

1918-512X (numérique)

Découvrir la revue

Citer cet article

Brook, T. (2017). Ascending Music: Meaning and Expression in the Chamber Music of Brian Cherney. Intersections, 37(1), 83-98.

https://doi.org/10.7202/1059888ar

\section{Résumé de l'article}

Cet article explore le langage musical de Brian Cherney, utilisant l'idée de sujets musicaux comme moyen d'analyser le contenu extramusical de la musique. L'auteur élargit l'idée de sujets musicaux, appliquée traditionnellement aux oeuvres de l'époque classique, en recourant à un éventail de sujets propres à l'oeuvre de Cherney. Axé sur un ensemble de pièces de chambre tirées de la production compositionnelle de Cherney commençant dans les années 1960, cet article met tout particulièrement l'accent sur le sujet de la " musique ascendante ", traçant le sens musical et expressif dans ces oeuvres de chambre. L'auteur conclut son article par une analyse thématique de Gan Eden, une composition pour violon et piano de 1983, donnant ainsi un exemple de la façon dont les divers sujets coexistent et interagissent dans une même composition.
Copyright (C) Canadian University Music Society / Société de musique des universités canadiennes, 2019
Ce document est protégé par la loi sur le droit d'auteur. L'utilisation des services d'Érudit (y compris la reproduction) est assujettie à sa politique d'utilisation que vous pouvez consulter en ligne.

https://apropos.erudit.org/fr/usagers/politique-dutilisation/ 


\title{
ASCENDING MUSIC: MEANING AND EXPRESSION IN THE CHAMBER MUSIC OF BRIAN CHERNEY
}

\author{
Taylor Brook
}

The chamber music of Brian Cherney has a striking expressiveness, a quality he achieved by developing a unique and coherent musical language. Cherney's music is fundamentally intertextual: saturated in allusion, reference, and symbols. Referential material is woven into the very fabric of the music: quotation of and allusion to the works of Beethoven, Mahler, Schoenberg, and others; stylistic references suggesting folk music traditions; bird calls and other sounds from nature.

These are some of the recognizable elements that point outward to other music and the sounds of nature, but there is also the self-contained world of his own music that points inward, relying on self-quotation and self-allusion. At the heart of this self-referential material is a set of recurring musical topics, each conveying some form of meaning and expressive possibilities. Cherney uses these topics to interact with the other elements of a piece, creating connections and narrative relationships.

Following a brief introduction discussing the analytical framework, this article will outline some of Cherney's musical topics, focusing on one of the more pervasive topics, "ascending music," showing how this topic evolves through decades of use in many pieces. This article will also consider a topicbased analysis of Gan Eden, Cherney's violin and piano duo of 1983, elucidating how musical topics are implemented in a piece and how the interplay of these topics may convey meaning.

\section{Topics, Meaning, And Expressivity}

I would like to make a brief aside to acknowledge the difficulty of discussing meaning and expression in music. A meaningful investigation would necessitate an exploration of the nature of music itself and is beyond the scope of this article. However, I would like to provide two quotations on this subject, from Jerrold Levinson and Anthony Newcomb, that may illuminate my approach: "A passage of music $\mathrm{P}$ is expressive of an emotion or other psychic condition $\mathrm{E}$ if [and only if] $\mathrm{P}$, in context, is readily and aptly heard by an appropriately backgrounded listener as the expression of E, in a sui generis, 'musical' manner, by an indefinite agent, the music's persona" (Levinson 1996, 107). "The flow of 
reference back and forth between musical objects and expressive meaningbetween extramusical and intramusical patterns - that is at the heart of musical expression" (Newcomb 1984, 623).

Levinson argues that musical expression depends on the listener's familiarity with the musical language or style being employed in a piece, that cultural knowledge is a prerequisite for expression. How the listener may become "appropriately backgrounded" is partially addressed in the Newcomb passage, which suggests a cyclic relationship between musical objects and expressive meaning. Eduardo De La Fuente claims that "some twentieth-century works can lay claim to being their own paradigm with their own set of technical and stylistic rules" (2011, 44). By expanding this idea from a single work to a body of work that constantly cross-references itself, we begin to understand how Cherney's music creates its own paradigm and suggests an invented tradition of music.

A somewhat analogous approach that suggests invented tradition in visual art has been recently theorized using terminology such as performatism (Eshelman 2002), conceptual romanticism (Heiser 2008), or metamodernism (Vermeulen and Akker 2010), where the artwork "oscillates between a modern enthusiasm and a postmodern irony, between hope and melancholy, between naïveté and knowingness, empathy and apathy, unity and plurality, totality and fragmentation, purity and ambiguity" (Vermeulen and van den Akker $2010,6)$. A metamodern approach retains some tenets of modernity and romanticism: a sincerity of meaning and the ability to address essential human themes of life and death.

Rather than deconstruction or pastiche, the inclusion of quotation and allusion may be understood as a sincere expression in the context of metamodernism. As Stephen Knudsen writes, "Metamodernism allows the possibility of staying sympathetic to the poststructuralist deconstruction of subjectivity and the self-Lyotard's teasing of everything into intertextual fragments-and yet it still encourages genuine protagonists and creators and the recouping of some of modernism's virtues" (2013). While Knudsen's comments pertain to literature and film, the same idea applies to Cherney's intertextual approach to composition. Cherney's musical language is assembled from many sources, constantly referring to and repeating itself. However, the goal of this musical language is genuine expression of musical and extramusical meaning.

The question of how meaning could be conveyed in Cherney's personal musical language, how a listener may be "appropriately backgrounded" as outlined by Levinson, may be addressed using topic theory. The theory of musical topics emerged in recent decades through the work of Agawu, Allanbrook, Caplin, Ratner, and others, and is usually applied to the study of eighteenth-century classical music. "Pastoral," "military," "French overture," and "hunt" are all examples of musical topics from that tradition. A topic may be an affect, style, genre, musical convention, musical pattern, or melodic figure that is imbued with meaning through cross-references within the tradition of classical music. Topics provide a framework through which musical material may take on poetic meaning and refer to the extramusical. Robert L. Martin 
writes that the importance of topics "derives from the commonplace nature of these kinds of music. Familiarity with them, and with their associations ... [provides] a musical link to the extramusical" $(1995,417)$.

Cherney creates many recurring musical ideas that could be considered topics, fulfilling the idea of a flexible musical sign that points to extramusical meaning. Some of the topics typically found in Cherney's music have been identified and discussed by Spiteri (2000, 82-4) and Ricketts (2017, 79), but identifying topics as a way of understanding Cherney's musical language remains largely unexplored.

Table 1. Cherney's Most Prominent Topics

\begin{tabular}{l}
\hline Ascending music \\
Blurry music \\
Cadenza \\
Imaginary folk music \\
Litany \\
Micropolyphony \\
Paradise music \\
Pseudo quotation \\
Quiet music \\
Stillness/stasis \\
Ticking music \\
Tolling music \\
\hline
\end{tabular}

The genesis of these topics is a mixture of traditional topic theory (cadenza, folk-like) and general terminology (micropolyphony, quiet music, pseudo quotation), as well as Cherney's own nomenclature (ascending music, blurry music, paradise music, etc.) (Brook 2016). These topics, however, are not provided in the musical scores and are instead identified by musical analysis, from Cherney's sketches, and through personal correspondence. Many of these topics originate from Cherney's earliest compositions in the 1960 and 1970 and remain present in his music today.

Not all the topics in table 1 are original to Cherney's music. References to the cadenza topic, for example, are found in many of his works, and these cadenzas are often used to help create a sense of formal balance and contrast. With this list I am stretching the definition of musical topics, treating the corpus of Cherney's chamber music as an ecosystem or tradition unto itself. A similar approach could be applied to many twentieth-century and twenty-firstcentury composers, who often attempt to "find their voice," and in doing so create their own systematic and self-referential approaches to composition.

\section{AsCending Music}

One of the most prevalent topics in Cherney's music is the "ascending music," which is, in essence, a passage of music that rises in pitch gradually to a high register, and then fades toward silence. "Ascending music" has several forms, 
but there are two main versions: a tremolando version reminiscent of Ligeti's micropolyphony, and a chordal or scalar version employing a barbershop-pole effect. Both versions of ascending music have a cloud-like quality where the individual parts, the chords, scales, or tremolondi, combine to form an amalgamation of sound that gradually ascends in pitch.

This topic has a spiritual aspect, symbolizing the soul passing into the afterlife; Cherney often includes "ascending music" in pieces dedicated to the deceased. While "ascending music" is musically satisfying in and of itself, especially when listening through the body of work-coming across so many variations of the same idea-it does require textual explanation to fully comprehend the spiritual significance and imagery. This article will trace the development of "ascending music" through seven works:
1. Kontakion: Quiet Music for Eleven Players (1969)
2. String Quartet no. 2 (1970)
3. String Trio (1976)
4. Gan Eden (1983)
5. String Quartet no. 3 (1985)
6. In Stillness Ascending (1986)
7. Twenty-two Arguments for the Suspension of Disbelief (2010)

This is by no means an exhaustive list, as "ascending music" appears in many pieces besides these, each with slight variations. The seven works illustrate the flexibility of "ascending music" and how it may be truncated, extended, or mixed with other musical elements to create meaning.

The earliest instance of "ascending music" is found on page 10 of Kontakion: Quiet Music for 10 players, from 1969 (figure 1). Kontakion is the first of Cherney's works to break from the more traditional compositional models of his student years. The piece contains many of the principles and topics found in his music today: stillness, "ascending music," and many extended notational devices, for example. This initial version of "ascending music" is brief and doesn't extend to an extremely high register, possibly because the dynamic limitations of the instruments prevent an effective decrescendo to niente in any higher register.

At measure 249 of String Quartet no. 2, we find a more developed version of the "ascending music" from only one year after Kontakion (figure 2). In this example, the trills combine to form a chromatic cluster of pitches that spans from $\mathrm{G}_{4}$ to $\mathrm{B}_{4}$, which then rise in pitch and fade out. The instruments decrescendo from double piano to quadruple piano as the pitches rise higher and higher, until the players eventually lift the bows from the strings and mimic playing without producing sound. This miming refers to the opening section of this piece, encouraging the listener to focus on the threshold between sound and silence. The string quartet instrumentation is especially well suited to this form of ascending music because the instruments have a homogenous timbre and an ability to execute tremolandi at any dynamic throughout their range.

In the String Trio (1976) six years later, the "ascending music" takes a form similar to the instance in String Quartet no. 2, but the beginning is elided by 

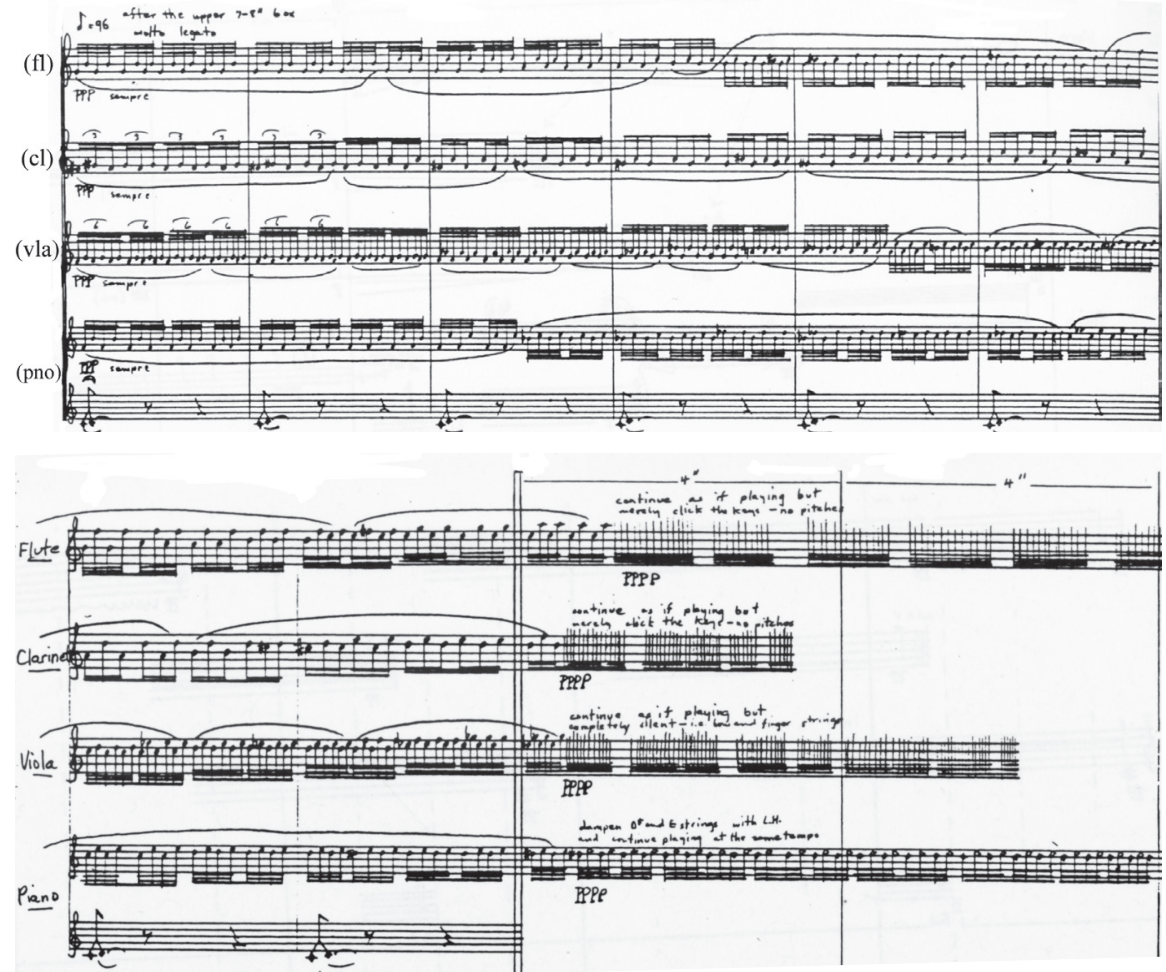

Figure 1. “Ascending music” from Kontakion: Quiet Music for Eleven Players (1969), p. 10

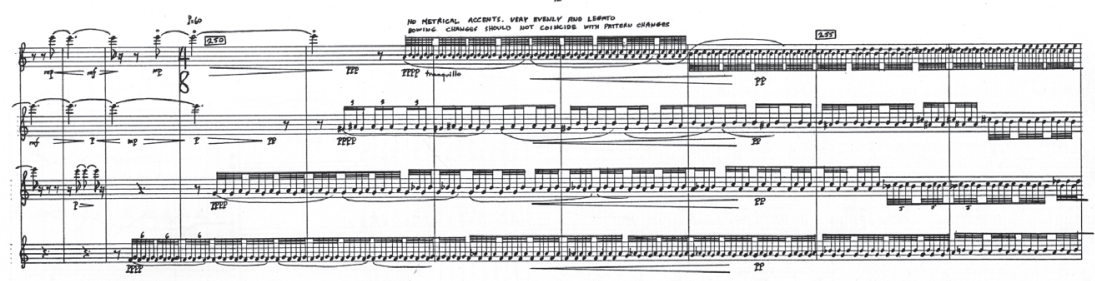
$=$

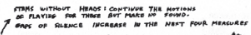

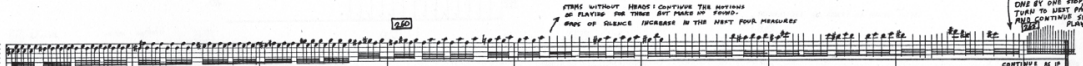

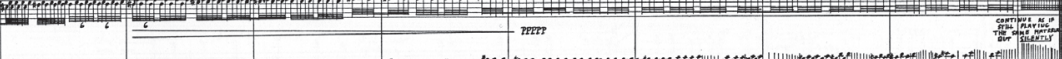
(2. \#1\% एom

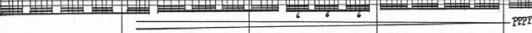

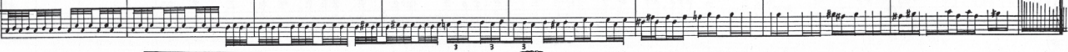

Figure 2. String Quartet no. 2 (1970), p. 12 

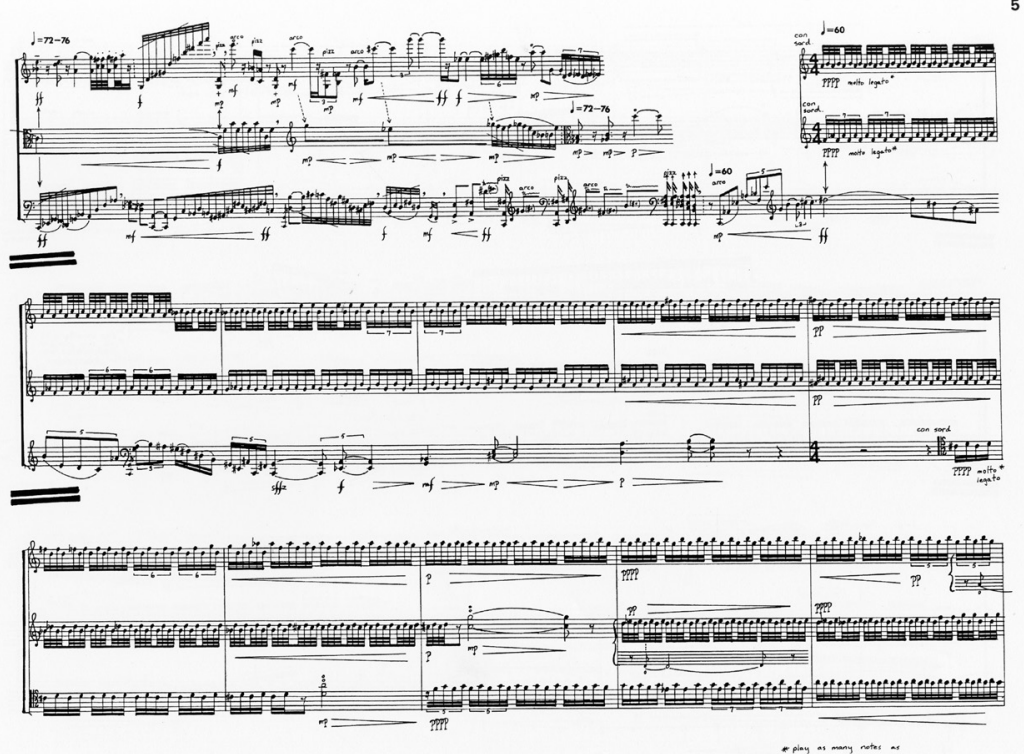

Figure 3. String Trio (1976), page 6
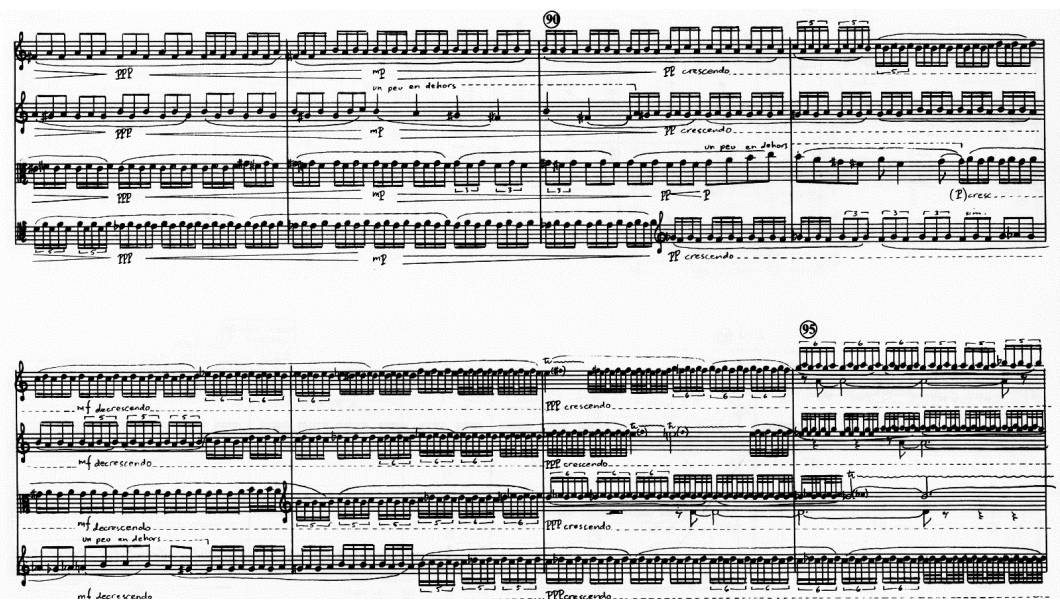

Figure 4. String Quartet no. 3 (1985), p. 12

a cello cadenza (figure 3 ). When the cadenza finishes, the ascending music is revealed in the background, already part way through. Additionally, as the "ascending music" continues, open string drones are added, an element that, as in String Quartet no. 2, refers to the opening section exploring the topics of stillness and stasis.

Moving ahead to 1985, String Quartet no. 3 contrasts the "ascending music" passage with lines that generally descend, evoking historical lament and sigh figurations that have been developed throughout this piece (figure 4). The 
"ascending music," portraying a soul's passing into the afterlife, is combined with lament and musical sigh figurations that symbolize mourning.

All of the pieces of music discussed thus far contain dedications to relatives, usually commemorating them. Kontakion is dedicated to the memory of Dr. Alexander Raxlen, the composer's uncle, a surgeon who lived and worked in Toronto. String Quartet no. 2 is dedicated to the memory of his mother. The String Trio is dedicated to his father, while String Quartet no. 3 is also dedicated to the memory of his father, containing several musical connections to the String Trio. The "ascending music" topic, with its symbolic meaning of a soul ascending into the afterlife, is naturally fitting for these dedications that speak to death and memorialization.

Returning to String Quartet no. 3, this iteration of "ascending music" is much longer and more elaborate and is combined with elements drawn from the entire quartet (figure 5). A recurring descending line and melodic figuration is embedded within the ascending music, and these elements eventually come to the fore as the ascending music ends in an extremely high register of the two violins.

After this moment, there is a tumultuous and turbulent cello solo, which then subsides and makes way for another type of "ascending music" in a scalar form.

This second instance of "ascending music" from String Quartet no. 3 (figure 6) is scalar, superimposing ascending scales at different speeds to form a unified, cloud-like texture. Altogether in this quartet there are eighty measures of "ascending music," amounting to slightly more than a third of the piece. Cherney describes the cello cadenza that sits between the two instances of "ascending music" as capturing an experience of seeing his father physically struggling when very close to the end of his life (Brook 2016) and the entire
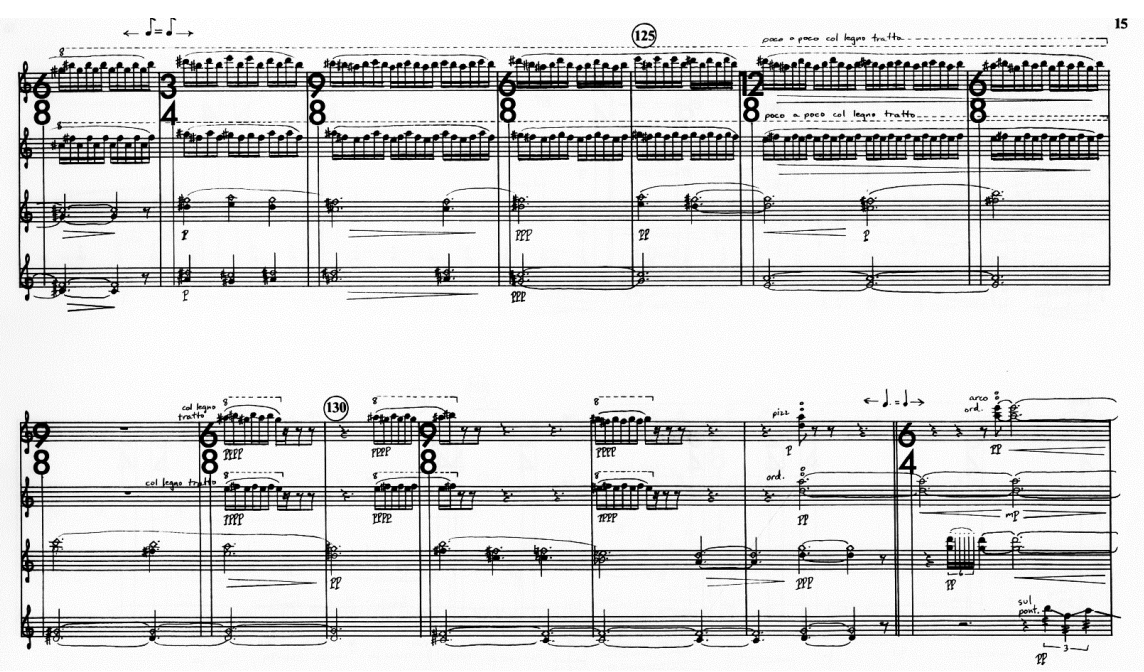

Figure 5. String Quartet no. 3 (1985), p. 15, conclusion of first instance of "ascending music" 


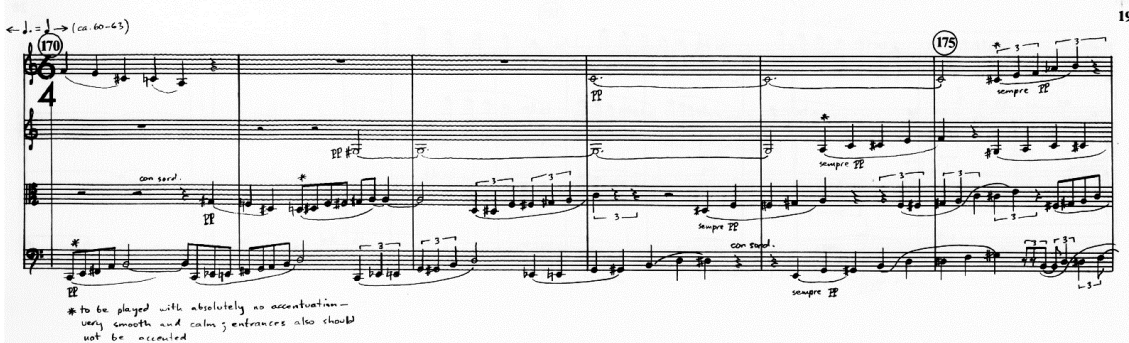

(180)

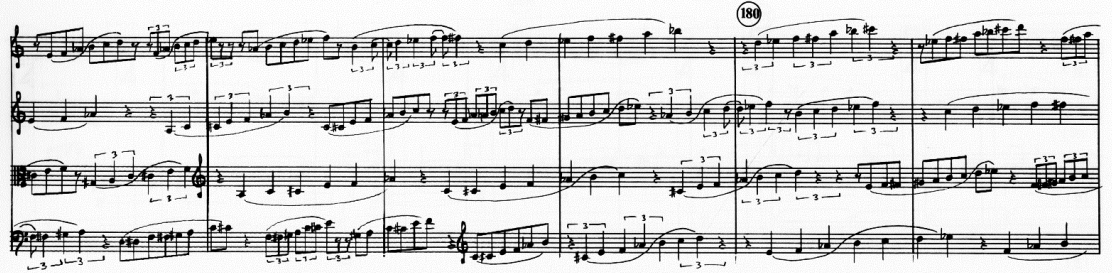

(185)
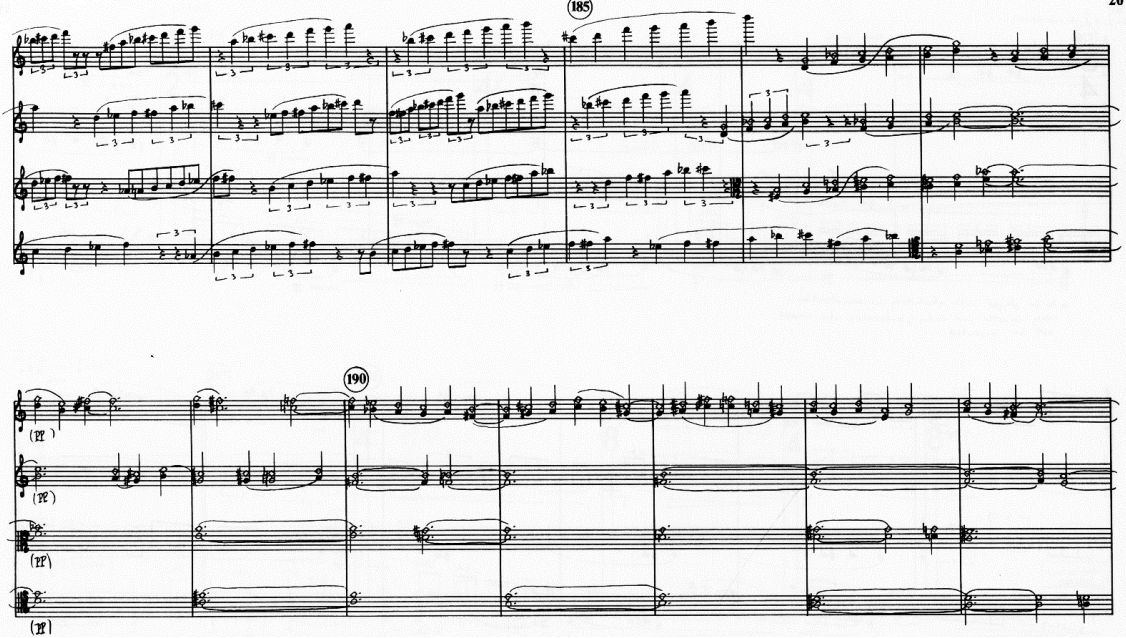

Figure 6. String Quartet no. 3 (1985), pp. 19 and 20, scalar form of "ascending music"

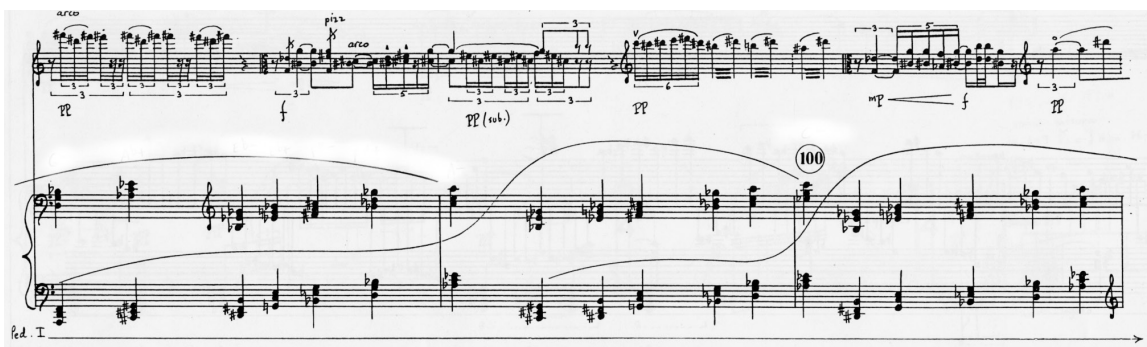

Figure 7. In Stillness Ascending (1986), chordal form of "ascending music" 
second half of String Quartet no. 3 can be understood in terms of struggling with death and dying.

One year after his String Quartet no. 3, Cherney wrote a duo for viola and piano titled In Stillness Ascending, which once again explores the topic of "ascending music" in multiple ways. Shown here (figure 7) is a chordal version of "ascending music" from measure 98 of In Stillness Ascending. This rendition is well suited to the piano, and we often find this chordal version in pieces involving the piano. This particular chord sequence is symmetrically constructed (figure 8) and methodically deployed between bars 97 and 110 (figure 9).

The chordal "ascending music" skeleton provided above was first realized in a piece for solo piano, In the Stillness of the Seventh Autumn (1983). The "ascending music" used here is performed exclusively on the piano as an

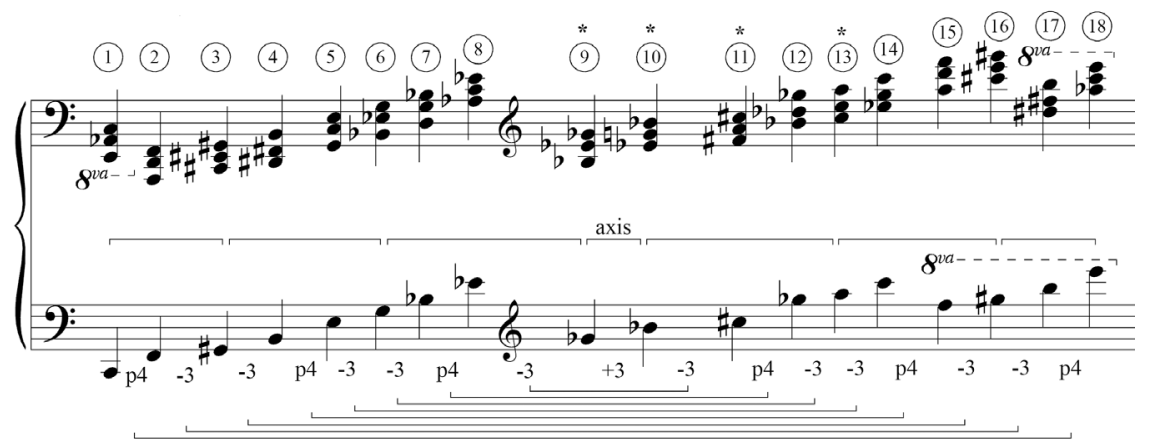

Figure 8. In Stillness Ascending array of chords for the chordal "ascending music"

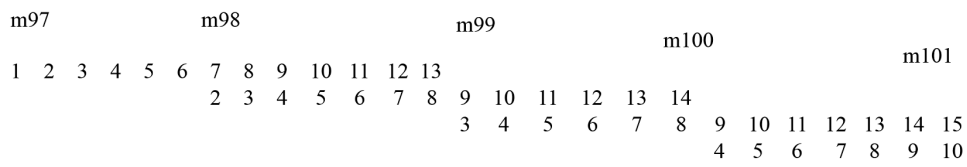

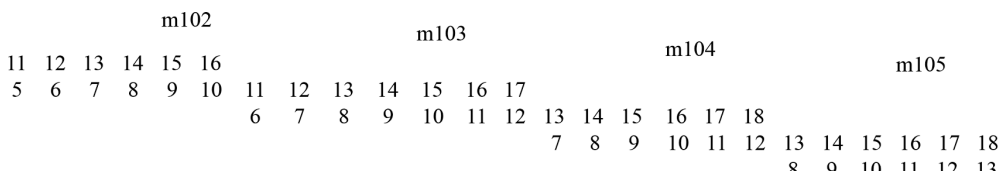

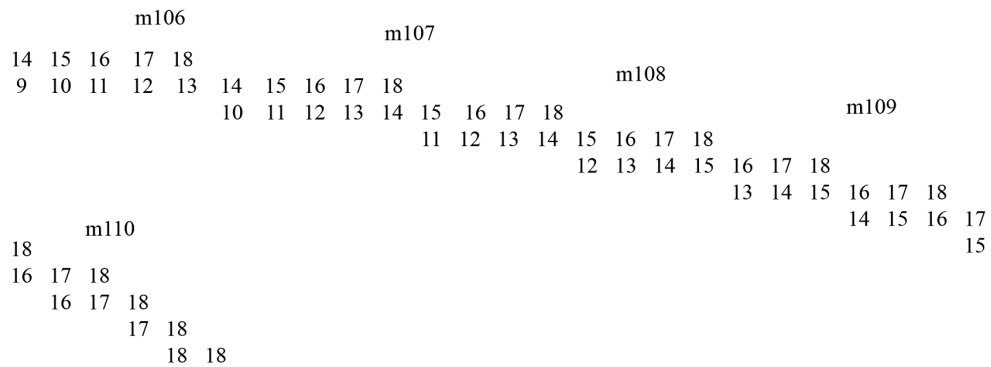

Figure 9. In Stillness Ascending structure of chordal "ascending music" 
accompaniment to a viola cadenza, contrasting the quiet calm of "ascending music" with a violent solo with the exact opposite trajectory of moving downward through the entire range of the viola. Figure 9, the structural chart, demonstrates how Cherney creates the barbershop-pole effect of the chordal "ascending music." An array of eighteen triads, with the uppermost notes forming a symmetrical line, are positioned in the piece as shown in the chart, with each ascent edging a little bit higher than the previous one.

In the 1990 and 2000 s the "ascending music" topic appears less often. However, the central idea-music that rises to the highest register and then fades away-remains a common gesture and still appears in various guises. In the 2010 trio for the Vancouver-based ensemble Nu:BC, Twenty-Two Arguments for the Suspension of Disbelief, Cherney moves the idea of "ascending music" to the structural level of the composition. Rather than "ascending music" appearing in a single phrase or section, the pitches gradually ascend over the course of the entire piece. The first system of the work is a loud and frenetic passage in the lower registers of the instruments. The ending is light and airy in the upper reaches of the instruments. In the twenty-two intervening minutes between the first and final phrases of this piece, the ascent in pitch plays out as a structural element that occasionally surfaces in the music but is not omnipresent.

\section{GAN EDEN}

Gan Eden, the violin and piano duo from 1983, is densely populated with topics, references, intertexts, and symbols. Figure 10, created by the author, illustrates when these topics appear in the piece. The evocative titling of the topics, such as "litany" and "paradise music," originates from Cherney himself (Brook 2016).

With the increasing use of referential topics, stylistic allusions, and direct quotations in Cherney's music throughout the 1980s, the passages of non-referential music become scarcer and begin to take on the function of a stage on which the referential materials play out. This "staging" music is by no means simply filler or devoid of expressive content, but it may lack the symbols and extramusical meaning that the referential music engenders. Instead, the "staging music" could be thought of as something like mood music or the "musica tinta" of opera.

Each of the topics in figure 10 could be analyzed and traced through Cherney's body of work in a way similar to "ascending music," and with this in mind one may begin to understand the web of references and layers of meaning that are built up through these topics and their intermingling.

The title of this piece, Gan Eden, refers to the Jewish image of the afterlife, a terrestrial or celestial Garden of Eden. The piece itself represents a garden with layered walls, and at the centre of this metaphorical garden is what Cherney calls "paradise music" (figure 11).

Cherney describes the overall narrative of this piece in terms of the garden as a metaphor for the soul "going from one layer to another until you arrive at the innermost being" (Brook 2016). "Paradise music" also appears in Cherney's 


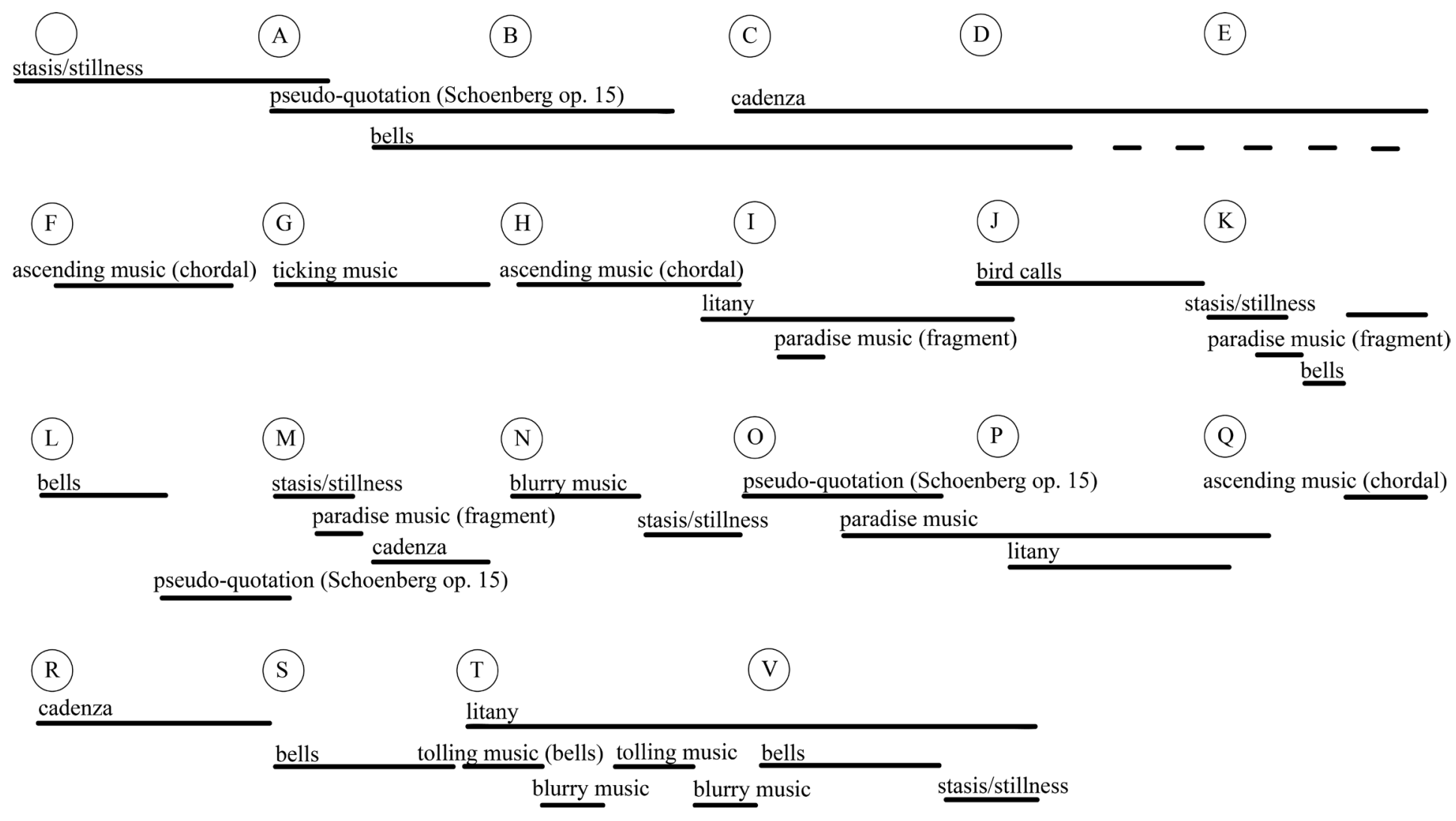

Figure 10. Gan Eden (1983) overview of topics with rehearsal letters 
12

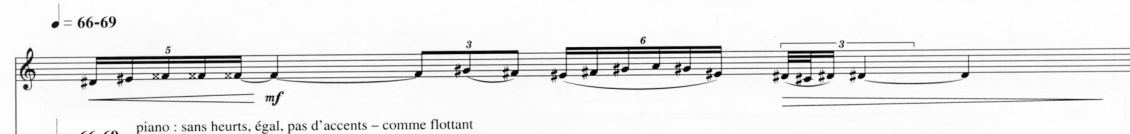

piano: very smoothly and evenly, no accentuation - as iffloating along ppp sempre

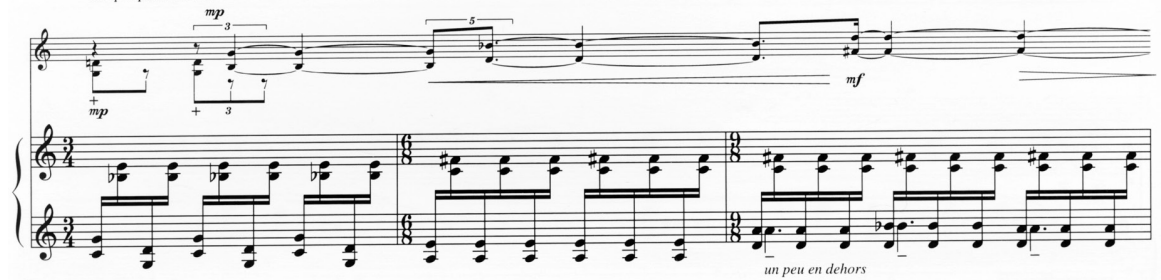
$\mathbf{P}$
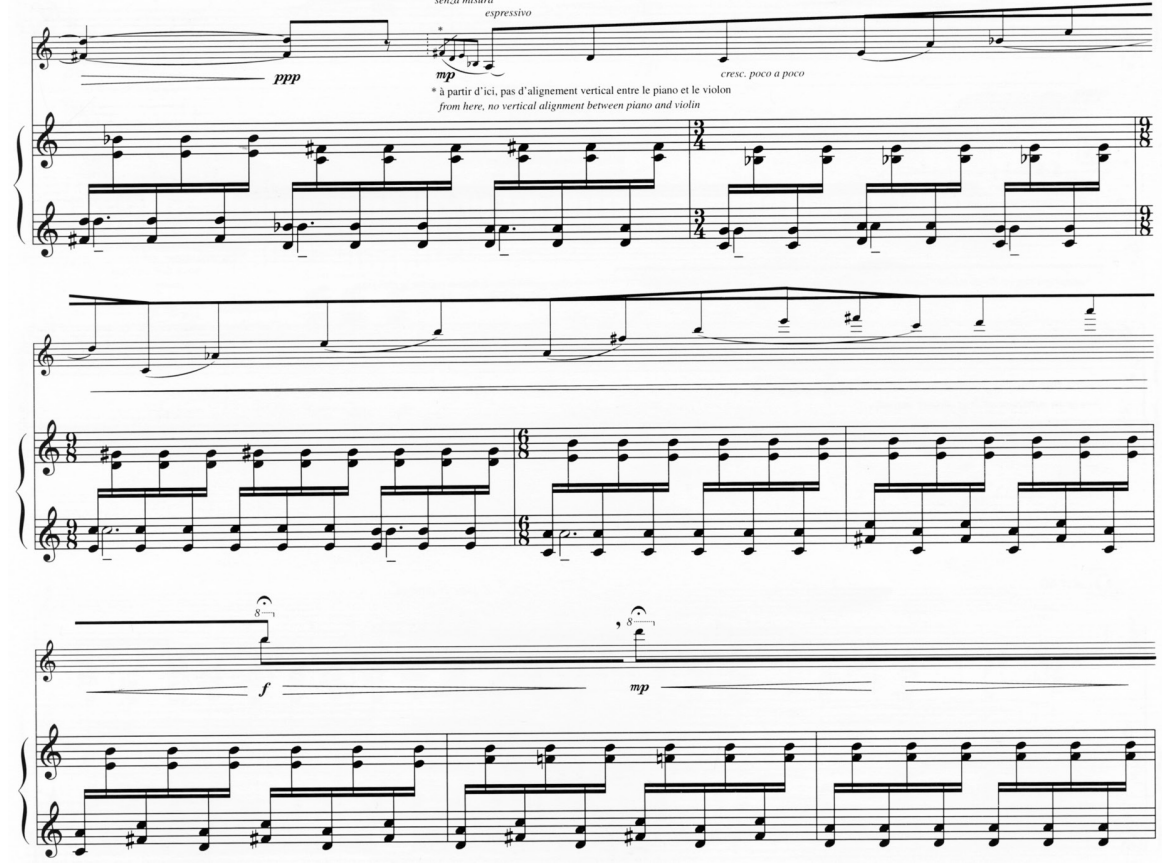

Figure 11. Gan Eden, p. 12, "paradise music" 


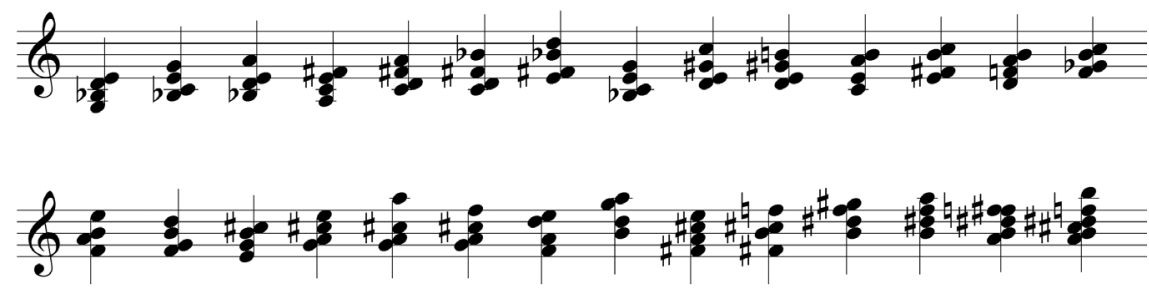

Figure 12. Gan Eden "paradise music" structure

orchestral work Into the Distant Stillness with the same significance of evoking paradise.

Harmonically, "paradise music" is made up of a series of tightly spaced chords, shown in figure 11, in the middle range of the piano, gradually ascending in pitch in a circuitous fashion. These chords contain four pitch classes each, with the exception of the final two chords, which contain five pitch classes each. The chords are primarily stacked thirds, though several quartal harmonies are also included. Dominant-seventh chords form the majority of the harmonies, providing a vague sense of tonality but without any clear resolution or direction. The piano orchestration, parallel voice leading, and harmonic ambiguity of the "paradise music" are reminiscent of Debussy, taking on a dreamy and hypnotic character.

While the piano plays the "paradise music," the violin performs a series of melodic fragments, culminating in a high and rising melodic line. As the violin climbs higher it also becomes softer, the melody taking on an expression similar to "ascending music," with the disintegration of the line as it rises in pitch. The violin music is ascending to paradise, represented by the music in the piano, and the interplay between "ascending music" and "paradise music" suggests that the soul is rising into the celestial realm of Gan Eden, to the innermost garden.

The opening and closing sections of Gan Eden are closely related, bookending the work with related material and form: the opening music emerges from silence, and the ending (figure 13) disappears into silence in an extremely gradual way. In both sections the piano player mimes hitting the strings inside the piano with a mallet, gradually coaxing out extremely quiet sounds from the instrument. In concert, this miming effect encourages the audience to strain their ears, focusing on the threshold of sound as they see the performer using mallets inside the piano, which is obscured by the body of the instrument, the performer's gestures suggesting sound that may or may not actually be present. While the beginning and ending are closely related, they are also opposites as one fades in and the other fades out, one in the low register and the other in the high register. Instead of a return that suggests a circular structure, the form of Gan Eden is more suggestive of an ascending spiral.

Commenting on the meaning of the violin melody at the end Gan Eden, Cherney states that he "thought of these as litanies ... a melodic figure that has a quality of suffocation ... has an almost ritualistic quality" (Brook 2016). As these "litanies" are played, they gradually slow down until finally becoming 


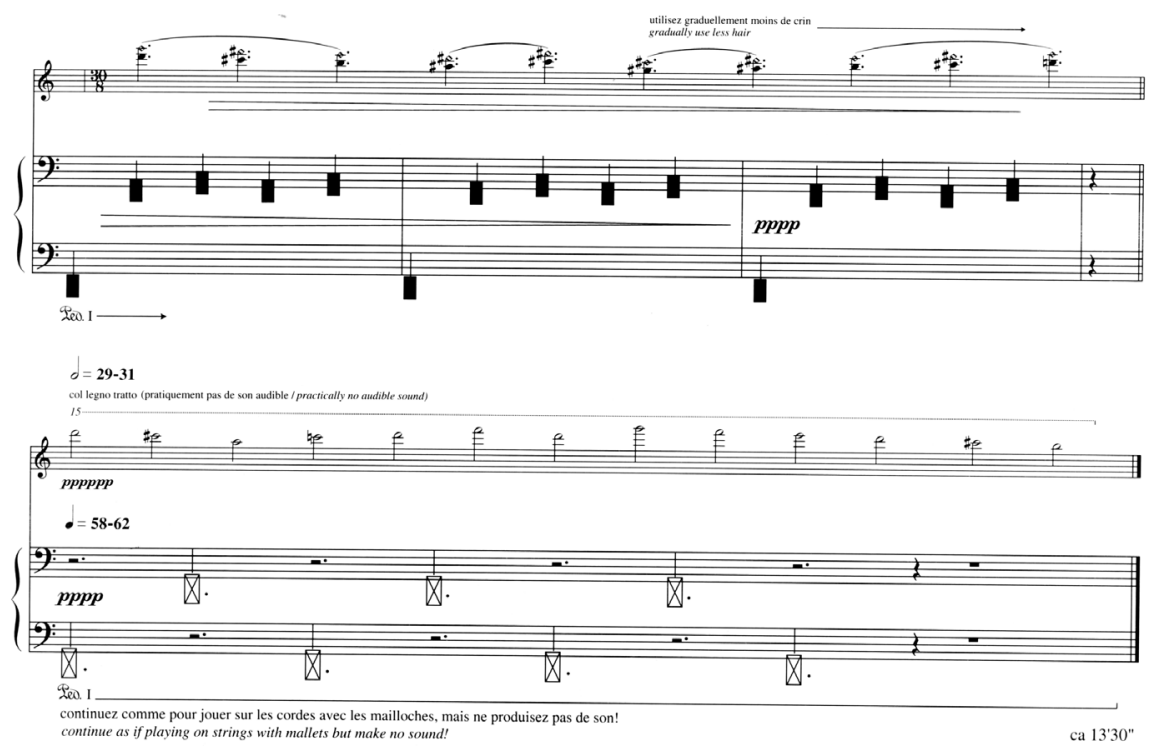

Figure 13. Gan Eden, final system, "litanies"

suspended in long notes in the highest register of the violin. The use of the word suffocation may be a reference to the point in which the soft music of the litanies becomes suspended in time and inaudibly quiet, evoking a last breath before death. This idea of a litany reflects an idea similar to "ascending music" and "paradise music"; the three musical topics are closely related through the use of melodic ascent and diminuendo, as well as the extramusical spiritual association.

\section{ConClusion}

Agawu claims that "the primary condition for topic perception is listener competence" $(1991,49)$. As the perception of classical topics relies on the listener's familiarity with eighteenth-century paradigms, so too the perception of Cherney's musical symbols requires an understanding of his topics. Many composers in the past hundred years have made the same demands on the listener, and indeed popular or folk traditions require the same attentiveness. Topics produce meaning for those who can recognize them.

After a discussion of musical expression, it is important to also acknowledge the limits of using words to ascertain musical meaning. The music itself should be enough, of course, without knowing a composer's specific intentions or hidden meanings. Cherney's music simultaneously balances symbolic topics with a sense of musical syntax that is complete in and of itself, but an understanding of these topics does enrich appreciation for the music. I conclude with a quotation from Daniel Albright that ruminates on this very issue of expressing musical meaning in words: "We are left in paradox: the more we try to understand music as language, the more strongly it resists that understanding; and the more we try to understand music as the opposite of language, the more 
sweetly, strongly, plainly it speaks to the ear. We understand the siren's song only at the moment when we stop trying to understand it" (2014, 177).

\title{
REFERENCES
}

Agawu, Kofi. 1991. Playing with Signs. Princeton: Princeton University Press. Albright, Daniel. 2014. Panaesthetics: On the Unity and Diversity of the Arts. New Haven, CT: Yale University Press.

Brook, Taylor. Interview with Brian Cherney. Montreal, 27 October 2016.

De La Fuente, Eduardo. 2011. Twentieth-Century Music and the Question of Modernity. New York: Routledge.

Eshelman, R. 2002. "Performatism, or, What Comes After Postmodernism: New Architecture in Berlin.” ArtMargins (April 2002). http://www.artmargins. com/index.php/archive/322-performatism-or-what-comes-after-postmodernism-new-architecture-in-berlin.

Heiser, Jörg, ed. 2008. Romantic Conceptualism. Bielefeld: Kerber.

Knudsen, Stephen. 2013. "Beyond Postmodernism: Putting a Face on Metamodernism without the Easy Clichés." ArtPulse, Winter. http:// artpulsemagazine.com/beyond-postmodernism-putting-a-face-on-metamodernism-without-the-easy-cliches.

Levinson, Jerrold. 1996. The Pleasures of Aesthetics: Philosophical Essays. Ithaca, NY: Cornell University Press.

Martin, Robert L. 1995. "Musical 'Topics' and Expression in Music.” Journal of Aesthetics and Art Criticism 53 (4): 417-24.

Newcomb, Anthony. 1984. "Sound and Feeling." Critical Inquiry 10:614-43.

Ricketts, Matthew. 2017. "Texts-Textures-Intertexts: The Orchestral Worlds of Brian Cherney.” DMus diss., Columbia University.

Spiteri, Vivienne. 200o. "Déploration: In Memoriam Morton Feldman by Brian Cherney, and in Conversation." Contemporary Music Review 19 (4): 73-103.

Vermeulen, Timotheus, and Robin van den Akker. 2010. "Notes on Metamodernism." Journal of Aesthetics \& Culture 2 (1). https://www.tandfonline.com/doi/full/10.3402/jac.v2io.5677.

\begin{abstract}
This article investigates the musical language of Brian Cherney, applying the idea of musical topics as a strategy for analyzing the extramusical content of his music. The idea of musical topics, traditionally applied to works from the classical era, is expanded with a collection of topics that are specific to Cherney's work. Focusing on a set of chamber pieces from throughout Cherney's compositional output beginning in the 1960 , this article focuses particularly on the topic of "ascending music," tracing its musical and expressive meaning through these chamber works. The article concludes with a topic-based analysis of Gan Eden, a 1983 piece for violin and piano, providing an example of how topics coexist and interact within a single composition.
\end{abstract}




\section{RÉSUMÉ}

Cet article explore le langage musical de Brian Cherney, utilisant l'idée de sujets musicaux comme moyen d'analyser le contenu extramusical de la musique. L'auteur élargit l'idée de sujets musicaux, appliquée traditionnellement aux œuvres de l'époque classique, en recourant à un éventail de sujets propres à l'œuvre de Cherney. Axé sur un ensemble de pièces de chambre tirées de la production compositionnelle de Cherney commençant dans les années 1960, cet article met tout particulièrement l'accent sur le sujet de la «musique ascendante ", traçant le sens musical et expressif dans ces œuvres de chambre. L'auteur conclut son article par une analyse thématique de Gan Eden, une composition pour violon et piano de 1983, donnant ainsi un exemple de la façon dont les divers sujets coexistent et interagissent dans une même composition.

\section{BIOGRAPHY}

Taylor Brook is a Canadian composer living in New York, writing and producing music for concert, film, theatre, and dance. Described as "gripping" and "engrossing" by the New York Times, his compositions have won numerous awards and prizes. Brook's music is often concerned with finely tuned microtonal sonorities, combining his interest in exploring the perceptual qualities of sound with an individual sense of beauty and form. 